\title{
APPLICATION OF REMOTE-SENSING TECHNOLOGIES FOR DETERMINATION OF TYPES OF LAND USE
}

Velta Parsova ${ }^{1}$, Armands Celms ${ }^{1}$, Virginija Gurskiene ${ }^{2}$, Evelin Jurgenson ${ }^{3}$

${ }^{1}$ Latvia University of Life Sciences and Technologies, Latvia; ${ }^{2}$ Aleksandras Stulginskis University,

Lithuania; ${ }^{3}$ Estonian University of Life Sciences, Estonia

velta@parsova.lv, armands.celms@inbox.lv, virginija.gurskiene@asu.lt, evelin.jyrgenson@emu.ee

\begin{abstract}
Type of land use is a territory of land surface according to its natural characteristics and the current economic use of the land. In relation to the changing economic environment, land monitoring institutions are investigating and implementing methods for obtaining new data on land use pattern. With the development of technologies, research on innovative methods of land resource assessment is becoming more and more relevant, which improves and accelerates the process of determining the land use pattern within the territory. In the article classifications of types of land use in Estonia, Latvia and Lithuania (hereafter - Baltic countries) have been compared and the possibilities of determination of types of land use applying remote sensing technologies analysed. There Open Source Geographic Information System (QGIS) capabilities are analysed. The results of the research were approbated on the example of rural area within Luznava municipality of Latvia for updating of types of land use within real property land parcel.
\end{abstract}

Keywords: land parcel, land resource assessment, mapping, remote sensing, type of land use.

\section{Introduction}

Investigation and analysis of land cover is an object of international initiatives, i.e. the United Nations Framework Convention on Climate Change (UNFCCC) and Kyoto protocol. Natural potential of the territories is conceptually based on differentiation of the landscape within the territory. Types of land use are territories, natural conditions and economic use of which for long lasting period is different. Generally types of land uses in many countries have been grouped as follows: settlements, traffic, agriculture, forestry, natural areas (vegetated and non- vegetated), and water systems [1].

Information on types of land use in Estonia, Latvia and Lithuania (hereafter - Baltic countries) is acquired and accumulated, because it is necessary for governments and scientists to develop their understanding and monitoring of the changes affecting the environment. Every Baltic country has its own land cover classification (Table 1).

Table 1

Classification of types of land use

\begin{tabular}{|c|c|c|}
\hline Estonia & Latvia & Lithuania \\
\hline \multicolumn{3}{|c|}{ Agricultural land } \\
\hline cultivated land and arable land & arable land & arable land \\
\hline X & orchards & gardens \\
\hline \multirow{2}{*}{ natural grassland } & meadows & \multirow{2}{*}{$\begin{array}{c}\text { meadows and natural } \\
\text { pastures }\end{array}$} \\
\hline & pastures & \\
\hline \multicolumn{3}{|c|}{ Non-agricultural land } \\
\hline forests and woodland & forests & forests \\
\hline $\mathrm{X}$ & scrubs & $\mathrm{X}$ \\
\hline $\mathrm{X}$ & swamps & swamps \\
\hline $\mathrm{X}$ & land under water and fish ponds & land under water \\
\hline yard land & $\begin{array}{c}\text { land under buildings and } \\
\text { courtyards }\end{array}$ & built-up area \\
\hline $\mathrm{X}$ & land under roads & roads \\
\hline other land & other land & $\begin{array}{c}\text { other land (trees and shrubs, } \\
\text { swamps, damaged land, } \\
\text { unused land) }\end{array}$ \\
\hline
\end{tabular}

Fig.1 shows that the composition of land cover in Estonia and Latvia is quite similar but in Lithuania the proportion of agricultural land is higher [2]. 


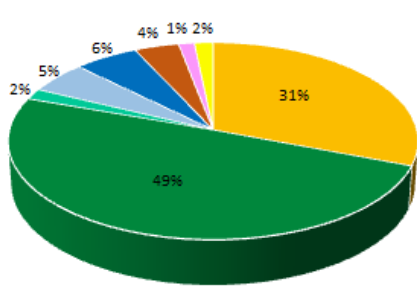

Estonia

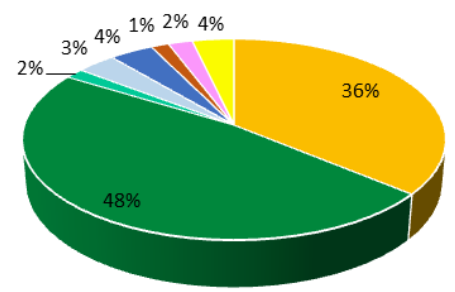

Latvia

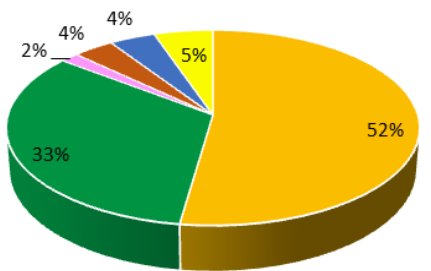

Lithuania

Agriculture land $\quad$ Forests

Scrubs

Swamps

- Built-up area = Land under water

At present types of land use in the Baltic countries usually are determined in two ways - only cadastral land surveyor conducting land cadastral surveying in the field is authorised to determine types of land use according to their actual natural conditions and evaluate the compliance of the use of particular territory with the set criteria (case of Latvia and Lithuania), and land cover data are changed, if topographical data are changed (case of Estonia).

Pattern of types of land use and their areas are constantly changing both, as a change in natural conditions and human activities. In the climatic conditions of Latvia, in the absence of land reclamation or in bad management of agricultural land, its gradual overgrowth and bogging-up is taking place. Also people often are taking targeted actions to turn one type of land use into another. Changes in land cover composition are closely related to the general level of agricultural production and land management. During a period of time the area of forests, scrubs, swamps, waters, courtyards and roads has been increased but the amount of agricultural land - decreased. People do not consider farming as a priority and a source of livelihood, therefore grassland and abandoned areas are increasing, fields are overgrowing with scrubs and gradually are becoming forests, and bogged areas are developing. The change of types of land use also is required, if is impossible to use the land for the intended purpose [3].

Since the restoration of independence, in the Baltic countries continuously an overview (survey) on land cover is provided. It is performed by registering and updating data in the Cadastre information system. An analysis shows that overall changes in land use patterns are relatively small. The authors' opinion is that land survey data do not fully reflect the changes in land use patterns, because only information acquired by land surveyors is updated in the Cadastre information system. That means there is maintained both newly updated information and old one, which is obtained, for example, 15 years ago. Updating of information for public administration is a great problem. With the development of the requirements for modern economic environmental information, the demand for the most up-todate information in limited time periods is increasing rapidly. In order to improve the actuality of cadastral information, land monitoring institutions in the world and also in Latvia have been looked for development and introduction of new technical and technological solutions in practice. In order to estimate agricultural land area more accurately, it is recommended to arrange and periodically renew the mapping data. The Land (Cadastre) Information System should include mapping of land use. These data should be used for agrarian territory management and land improvement planning $[4 ; 5 ; 6]$. In the territorial structure of rural landscape agricultural farming land prevails. Almost in all European countries the tendency toward decrease is noticeable. Only in few countries the agricultural land area has increased - the most in Bulgaria, as well as in Portugal, etc.

New technological solutions allow to accelerate land use identification processes for obtaining the most up-to-date and accurate information on changes in land use patterns, giving higher quality potential for the performance of public administration functions, reducing the costs of work and improving the number of other indicators [7-9].

The novelty of the research is the study of issues related to the application of space photography technology in various sectors. Today satellite information is widely used in GPS, telecommunications and other sectors, but not in real property cadastre. Therefore, investigations on remote sensing methods in determining the land use patterns give significant contribution to the integration of innovations for the cadastre needs. Topical problem also is compatibility of detection technologies with other systems, e.g., GPS, and diverse use of obtained data [10;11]. 
The authors focused on investigation of the possibilities of modern remote-sensing technologies using satellite-based data and satellite information processing software, for final analysis using the open-source Geographic Information System (GIS) software. The aim of the research is to describe the classification of land use types and criteria for their determination, to find out the methods for improvement of determination of types of land use by remote sensing means and develop proposals for improvement of land use patterns.

The aim of the article is to compare classification of types of land use in the Baltic countries, to analyse the possibilities of determination of types of land use applying remote sensing technologies and the Open Source Geographic Information System (QGIS) capabilities.

\section{Materials and methods}

Analysis of use of remote sensing methods in determination of types of land use is based on use of the Open Source Geographic Information System (QGIS), which is licensed under the General Public License (GPL). In accordance with this license it is allowed to view and modify the source code, as well as download software free of charge. The user of QGIS has an opportunity to create, edit, visualize and analyse geospatial information, and also copy the data from one source to another, as well as search and view data and metadata, export layers to specific configurations and coordinate systems. These advantages of QGIS software were used in the research.

Information recorded in the Cadastre Information System, such as situation plans, maps of qualitative assessments of the land was used. Technical justification of measures of determination of types of land use is approbated on an example of real property "Irbenes" within Luznava municipality of Latvia.

To achieve the goals and objectives of the research appropriate methods have been used- analysis of scientific literature, mathematical calculation methods, analysis of documents and factual materials. To give a practical expression of the research results, the authors applied the following methods:

- landscape-ecological approach - to study the location (geosystem) as a multi-structural system;

- cartographic method - for visualisation of proposals;

- modelling method - for formation of types of land use, as well as abstract-logical method - to generalize and outline conclusions.

\section{Results and discussion}

In the current technological development period research on innovative and robotised methods for surveying and evaluation of land resources is becoming topical, because it is very important to improve and accelerate the implementation of detection processes. The remote sensing issue has been studied in the world, including the European countries in the context of improvement of cadastre information [1].

In the Baltic countries studies have been carried out mainly on the use of remote sensing data for discovering of land cover changes, development of rural area map, identification of ravines separate trees in mixed forests. Researchers and specialists already have investigated the possibilities of various technological solutions. Researchers at the Rezekne Academy of Technologies and the Latvia University of Life Sciences and Technologies for several years have elaborating remote sensing and laser scanning methods for automated updating of building data within the Cadastre information system, as well as for automated identification of terrain objects and for establishment and maintenance of the national border [11].

To evaluate possibilities of application of remote sensing in updating of types of land use, as the object of the research for approbation of the results the land parcel of real property "Irbenes", which is located in the east part of Latvia, was chosen. Land parcel boundaries were allocated in 1998 using a simple (cartographic) method. Total are of the land parcel is $7.7 \mathrm{ha}$, and it consists of agriculture land (2.2 ha), forests (4.8 ha), swamps (0.2 ha), land under roads ( $0.1 \mathrm{ha})$ and other land (0.4 ha). $2.2 \mathrm{ha}$ of agriculture land are ameliorated (Fig. 2). Aerial and satellite images are among the most informative data sources for geospatial data (GIS) databases. For research activities the orthophotomap, produced 
by the Latvian Agency of Geospatial Information, was used. This map was matched with relevant cadastral data using the capabilities of the Geographic Information System software QGIS (Fig. 3).

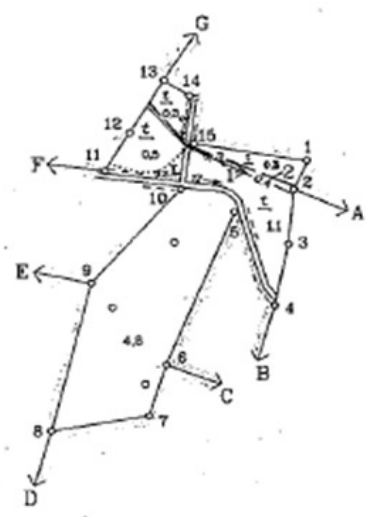

Fig. 2. Boundaries of land parcel and
types of land use

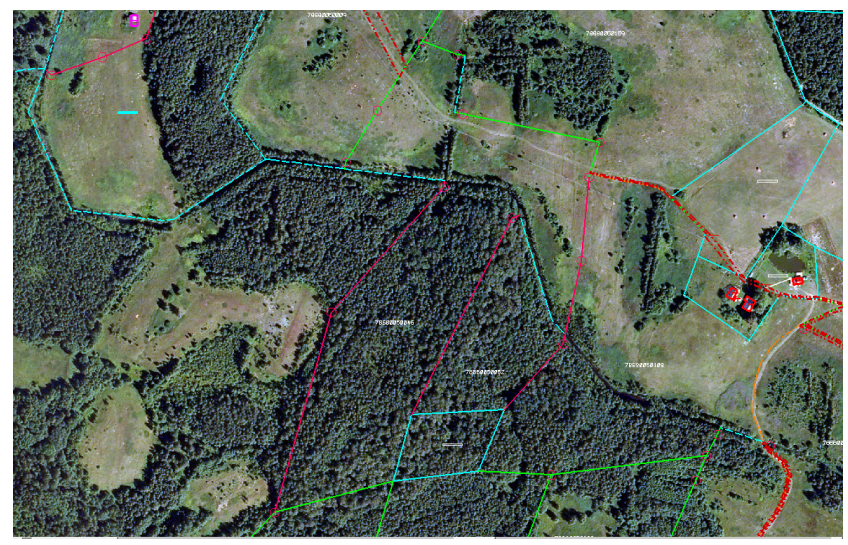

Fig. 3. Cadastral data matched with orthophotomap

For determining the land use patterns using the QGIS software, it is necessary to download the metadata about the region, where an object - particular land parcel - is located. The satellite image Landsat8 was downloaded from the web site: earthexplorer.usgs.gov. There was chosen a satellite image made in the spring period with the smallest cloud cover. In QGIS software the metadata file Landsat 8 was connected, there an algorithm was used for data correction, which is required to operate the recognition algorithm.

Further such well-known material as satellite imagery Landsat 8 was used, where the Geographic Information Systems software QGIS was used for manipulating the image. This increased the resolution of use of the satellite image and brought it closer to the planned research area. Increasing the resolution of the satellite image to the maximum planned research area was marked and "cut" out. For selected area full-color high-resolution satellite image was used (Fig. 4). In the images examples for identification were manually selected: for agricultural land (arable land, meadows and pastures) white, abandoned agricultural land (fallow land) - light green, for forests - dark green and for water blue. The mentioned parameters were set up in the analysis program. After implementation of settings into the image analysis program, there was obtained an image, which was transformed in accordance with the types of land use. Each new pixel of the image was assigned with a certain type of land use (Fig. 5).

Further the program provided numerical parameters of land use patterns (Fig. 6). Afterwards, the identification of belonging of pixels covering the land parcel was made, for example, land parcel boundaries were designated and pixels of generated images identified belonging to the land use patterns (Fig. 7, 8). The pixels were summed up according to their belongings and the pixel-bound area was determined, creating an area calculation.

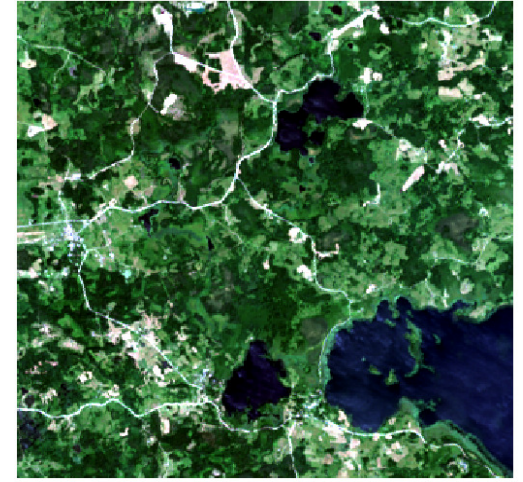

Fig. 4. Planned research area on colourful Landsat 8 satellite image

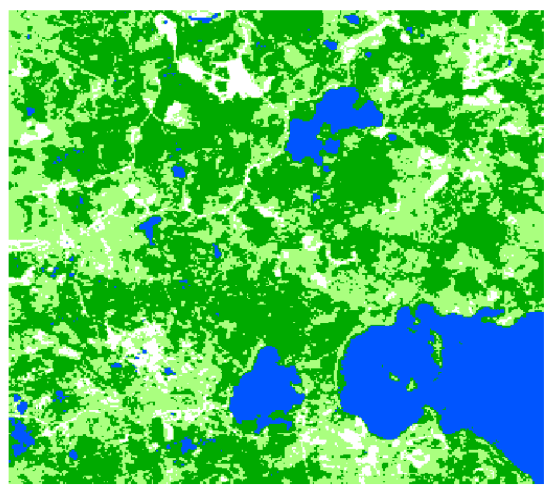

Fig. 5. Landsat 8 with recognised types of land use 


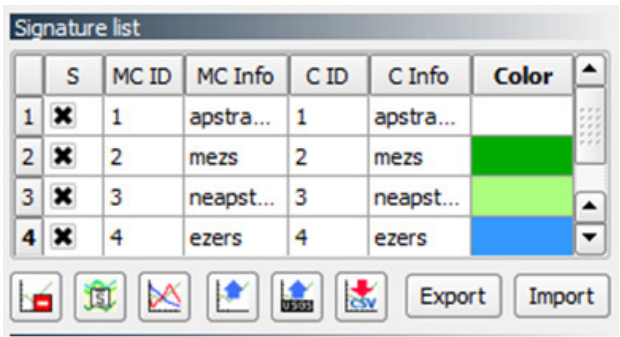

Fig. 6. Numerical parameters of types of land use

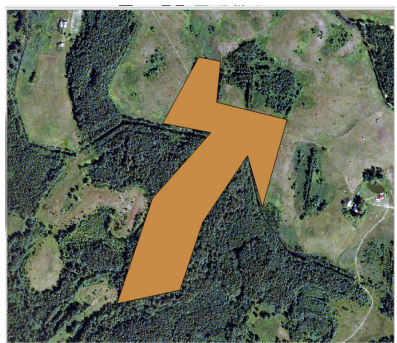

Fig. 7. Territory of land parcel

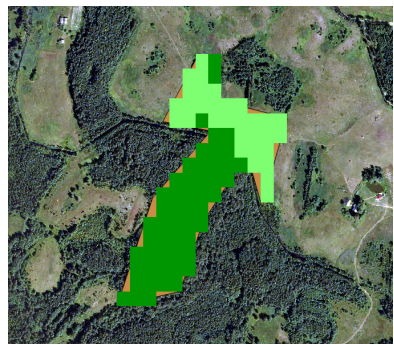

Fig. 8. Recognised types of land use

Calculation of the area of types of land use was made. The result is that forests (code No. 2) cover 0.09 ha and abandoned land (code No. 3) - 6.24 ha.

It can be concluded that using QGIS different and actual land use patterns were determined, comparing with the determined in 1998. To check the results of use of QGIS software for determination of land use patterns a field survey was made (Fig. 9, 10).

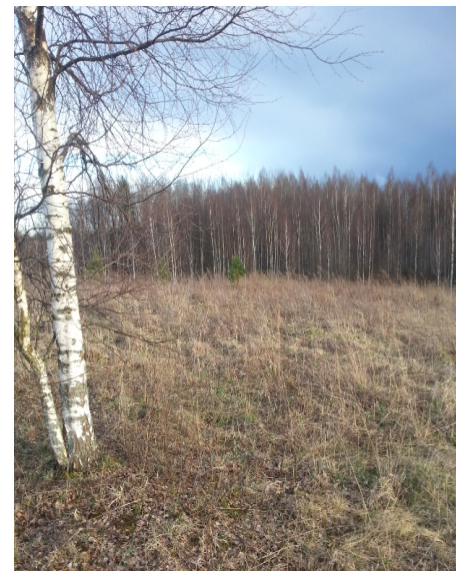

Fig. 9. Agriculture land overgrown with forests

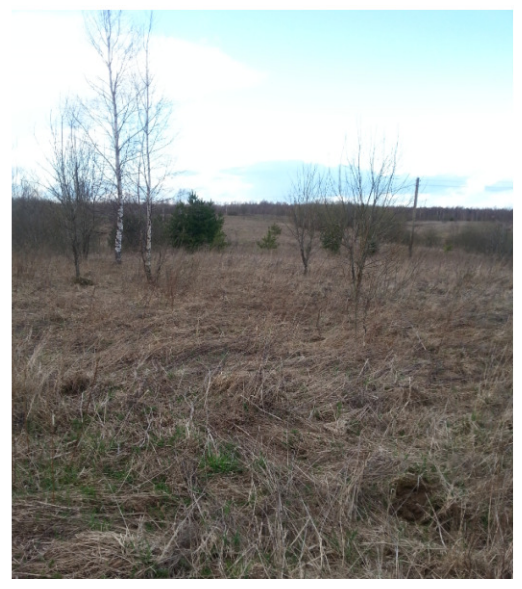

Fig. 10. Abandoned agriculture land

The investigation showed that costs of cadastral surveying of particular land parcel make up about 627 EUR, the expenses of using the remote sensing method make up about 70 EUR, including:

- QGIS software - free of charge;

- Landsat 8 - free of charge;

- $\quad$ work of operator - 31 EUR;

- field survey - 38 EUR.

The comparison of the costs using the traditional method and the remote sensing method shows a significant reduction of costs in favour of the remote-sensing technologies. Even adding to the future costs control-verification procedures, the difference will remain very significant. There will be a significant saving of state resources or it will allow increase the frequency of data updating within the framework of the existing financial resources.

\section{Conclusions}

1. The use of remote-sensing methods ensures that the land use patterns are identified in the Cadastre information system; it increases the accuracy of the results and reduces the cost of actualization of land use types.

2. It is necessary to improve the methods for determination of the existing land use patterns, information updating should be one of the priorities of maintenance of the Cadastre information system and it is desirable to use remote-sensing data in order to improve the methods of detection of types of land use.

3. The use of satellite imagery and appropriated software allows to update land use patterns instead of field surveying, or amount of which can be significantly reduced. 
4. Identification of types of land use by remote sensing methods can significantly reduce the costs and shorten the time of the production of updated information.

\section{References}

[1] Manakos I., Braun M. (eds.). Land Use and Land Cover Mapping in Europe: Practices \& Trends, Remote Sensing and Digital Image Processing 18, Springer Science+Business Media Dordrecht, 2014. $441 \mathrm{p}$.

[2] Parsova V., Gurskiene V., Kaing M. Real Property Cadastre in Baltic Countries, Jelgava, Latvia University of Agriculture, 2012. 138 p.

[3] Paršova V., Jankava I. Zemes lietošanas veidu izmainas atkārtotā zemes kadastrālajā uzmērīšanā (Changes of types of land use in repeated cadastral survey), Rīga, RTU zinātniskie raksti "Ģeomātika", sērija 11, sējums 7, 2010, 57. - 62. lpp. (In Latvian)

[4] Bykoviene A., Pupka D., Aleknavičius A. Žemès ūkio naudmenų ploto apskaita ir pokyčių analizè Lietuvoje (Analysis of agricultural land area registration and its changes in Lithuania). Žemès ūkio mokslai (Agricultural sciences), 2014, Vol.21, 4, pp. 250-264. (In Lithuanian)

[5] Burget R.C., Colston J., Roy T., Zachary B. Geographic Displacement Procedure and Georeferenced data Release Policy for the Demographic and Health Surveys. Icf International, Calverton, Maryland, USA, 2013.

[6] Haaren C. V., Galler C., Ott S. Landscape planning. The basis of sustainable landscape development. Federal Agency for Nature Conservation. Gebr. Klingenberg Buchkunst Leipzig $\mathrm{GmbH}, 2008.52 \mathrm{p}$.

[7] Ratkevičs A., Celms A., Veliks A. Virsmas uzmērǐšana pielietojot bezpilota lidaparātu ar lāzerskanēšanas iekārtu (Surface measurement using an unmanned aerial vehicle with a laser scanner). Latvijas Universitātes 75. zinātniskā conference, Rīga, Latvijas Universitāte 2017. 265-266 lpp. (In Latvian).

[8] Begni G. Escadafal R. Fontannaz D. and Hong-Nga Nguyen A.-T. Remote sensing: a tool to monitor and assess desertification. Les dossiers thématiques du CSFD. Issue 2. 2005, $44 \mathrm{p}$.

[9] Šalkauskienė V., Gudritienė D. Georeferencinio pagrindo plotinių objektų atnaujinimas taikant $2015 \mathrm{~m}$. aerofotografijos duomenis (The update of areal objects of geo-referencing foundation using the data of aerial photography of 2015). Miškininkystė ir kraštotvarka (Forestry and Landscape Management). 2017, 2 (13), pp. 105-110. (In Lithuanian)

[10] Grigoriev A.N. "Method of radiometric distortion correction of multispectral data for the earth remote sensing". Scientific and Technical Journal of Information Technologies, Mechanics and Optics. 15 (4), 2015, pp. 595-602.

[11] Kodors S., Rausis A., Ratkevics A., Zvirgzds J., Teilans S., Ansone I. Real estate monitoring system based on remote sensing and image recognition technologies. Proceedings of Riga Technical University, Vol. 104, 2017, pp. 460-467. 